\title{
OUTBREAK OF TRAUMATIC DEFEAT FIRES IN BULGARIA - PUBLIC HEALTH ASPECTS
}

\author{
D. Dimitrova* \\ Department of Preventive Medicine, FPH, MU-Sofia, Bulgaria
}

\begin{abstract}
For Bulgaria fires are typical disasters. They create an outbreak of traumatic defeat with combined striking factors. The health consequences for society due to fires are a serious challenge. The purpose of the study is to analyze the public health aspects of the consequences of fires in the last five years. Methods. Statistical survey in Bulgaria for casualties of fires for the period 1995-2017 are analyzed. Results. The most affected by the fires are: Stara Zagora (over 2300), Dobrich (over 1800) and Burgas (near 1500) regions. The data indicate that the most common causes of the fires are technogenic - over $85 \%$, and nearly $10 \%$ are deliberate. Among the population the largest number (144 people) died in 2017, and the highest number (349) injured in 2012. Conclusions. There is a large number of people killed and injured in the country in the event of fires. The consequences for society are significant. Municipalities and teams of the single emergency system 112 have an action plan for fires and medical provision for the population. Since 2016 there is a methodology and mapping of the risk of fires on the territory of the country which improves the management and the public health activities.
\end{abstract}

Key words: outbreak of traumatic defeat fires; casualties; public health; Bulgaria

\section{INTRODUCTION}

Fires are one of the most widespread risks in the world today. Statistics on forest and field wildfires during the last 25-30 years are published in EU Forestry Monitoring Center reports. Observations in the EU member states during the period 1980 - 2005 show an increase in the number of areas affected by fires. (1-9)

For Bulgaria fires are typical disasters. They create an outbreak of traumatic defeat with combined striking factors. The health consequences for society due to fires are a serious challenge. (1-3)

\section{PURPOSE}

The purpose of this study is to examine and analyze the public health aspects of the traumatic defeat of the fires for the period 1995-2017, with an emphasis on the last five years.

\section{METHODS}

A database of NSI, Ministry of Interior, Bulgarian Academy of Sciences (BAS) and the

*Correspondence to: Dimitrova D., Department of Preventive Medicine, FPH, MU-Sofia, Bulgaria, Bulgaria, 1527, Sofia, Byalo more st., 8, Tel. 0889256810
European Forest Fire Database (EFD) has been applied and analyzed. The range - fires and fire hazard on the territory of the country. Data analysis covers a period from 1995 to 2017, with an emphasis on the last five years. Statistical units of the study - fires, medical casualties. Unit of measure - number and relative share. A descriptive, retrospective and comparative analysis of the medical casualties was made among the population in the country.

\section{RESULTS}

According to data of the Ministry of Interior, totally the most affected by fires for this period are the districts: Stara Zagora (over 2300), Dobrich (over 1800) and Burgas (near 1500) and Kurdzhali. (Table 1) $(5,6)$

The largest number and area burnt by forest fires were reported in Regional Forest Directorate /RFD/ Kardzhali - 91 fires burning 3495 ha, RFD Stara Zagora with 34 burning 695.5 ha and RFD Burgas with 45 fires affecting 497.5 ha. All of them are situated in South - Central part of the country. $(5,6,8$, 10)

According to the Executive Forest Agency database in 2016 the number of forest fires in Bulgaria was 584 and the burnt area is 
estimated to be 6340 ha. The average size per forest fire in 2016 increased to 10.8 ha. The biggest forest fire affected 871.7 ha of forest
DIMITROVA D.

territories, but the biggest fire burned more than 4500 ha, 500 ha of them in forest. $(5,6$, 11-16) (Figure 1)

Table 1. Level of fire risk in RFD (1991 - 2000 2.) (Source GD"FSCP" - MoI)

\begin{tabular}{lr}
\hline Level of fire risk & Regional Forestry Directorates (RFD) \\
Low & Ruse, Varna, Blagoevgrad, Shumen, Veliko Turnovo, Smolyan \\
Moderate & Sofia, Plovdiv, Burgas, Pazardzhik \\
High & Lovech, Kyustendil \\
Very high & Kurdzhali, Stara Zagora, Sliven \\
\hline
\end{tabular}

\title{
Forest fire statistics - Bulgaria
}

\author{
Bulgaria's statistic about forest fires
}

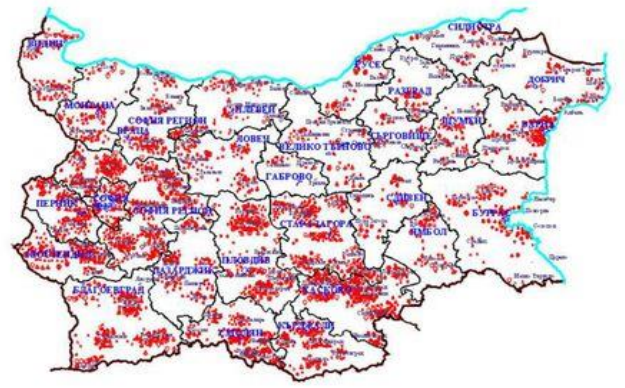

1994 to 2006

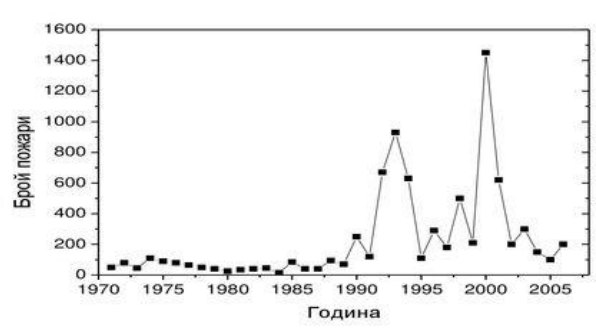

1971 to 2006

- considerable increase of the number of fires after 1990 (more than 1000 in year 2000)

- more than 30 times increase of the burned area in the recent years

Figure 1. Forest fire statistics - 1971-2006 (Source GD”FSCP” - MoI)

The data indicate that the most common causes of the fires are technogenic, and due to human negligence (unsealed beads, glass, fireburning) - about $90 \%$, and about $10 \%$ are deliberate. Only $1 \%$ are caused by lightning. (4-10) The MoI statistics show that almost $1 / 2$ of the fires are in the Housing and Communal Sector with a high-risk group of people with disabilities. About one-third of those killed in 2006 are from this social group. From official statistics by the ministry of forests, food and agriculture written in Bulgarian fires between 1970 and 2005 have huge incensement in the year 2000. (6) Among the population, totally the largest number (144 people) died in 2017, and the highest number (349) injured in 2012. (Table 2)

\section{DISCUSSION}

Fires are dynamic and with a variable risk of fire at a higher frequency in the summer. According to the data, the forest territory of our country accounts for $35.8 \%$ of the territory of the country. Of this area, $92 \%$ is covered with forests and the remaining $8 \%$ are nonwooded areas. Statistics show that the number of perished and injured people in Australia, Russia, Portugal, Italy, Greece, Bulgaria, Turkey and so on has increased as a result of the forest fires. $(6,16)$ In the case of fires, members of the rescue teams are also affected. $(8,13,16)$

The negative effects of fire include hazard to life and property, atmospheric pollution, and water contamination. Totally effects are social, ecological, economical, health. There are danger to life and health, loss of life or health. (Figure 2) (1-3, 6, 10, 15) 
DIMITROVA D.

Table 2. Statistics data on fires, deaths and injuries for the period 1995 to 2016 (Source GD"FSCP" -

MoI)

\begin{tabular}{|c|c|c|c|c|c|c|c|c|c|c|}
\hline \multicolumn{1}{|c|}{ YEAR } & $\mathbf{1 9 9 5}$ & $\mathbf{2 0 0 0}$ & $\mathbf{2 0 0 5}$ & $\mathbf{2 0 1 0}$ & $\mathbf{2 0 1 1}$ & $\mathbf{2 0 1 2}$ & $\mathbf{2 0 1 3}$ & $\mathbf{2 0 1 4}$ & $\mathbf{2 0 1 5}$ & $\mathbf{2 0 1 6}$ \\
\hline $\begin{array}{l}\text { With } \\
\text { material losse }\end{array}$ & 7621 & 11670 & 7540 & 8136 & 9487 & 9728 & 8503 & 7781 & 420 & 9058 \\
\hline $\begin{array}{l}\text { Without } \\
\text { material losse }\end{array}$ & 7437 & 26802 & 11430 & 16894 & 32403 & 35203 & 24401 & 15417 & 703 & 28304 \\
\hline \multicolumn{1}{|c|}{ TOTAL } & $\mathbf{1 5 0 5 8}$ & $\mathbf{3 8 4 7 2}$ & $\mathbf{1 8 9 7 0}$ & $\mathbf{2 5 0 3 0}$ & $\mathbf{4 1 8 9 0}$ & $\mathbf{4 4 9 3 1}$ & $\mathbf{3 2 9 0 4}$ & $\mathbf{2 3 1 9 8}$ & $\mathbf{1 1 2 3}$ & $\mathbf{3 7 3 6 2}$ \\
\hline
\end{tabular}

\begin{tabular}{|c|c|c|c|c|c|c|c|c|c|c|}
\hline \multicolumn{10}{|c|}{ DECEASED } \\
\hline AGE & $\mathbf{1 9 9 5}$ & $\mathbf{2 0 0 0}$ & $\mathbf{2 0 0 5}$ & $\mathbf{2 0 1 0}$ & $\mathbf{2 0 1 1}$ & $\mathbf{2 0 1 2}$ & $\mathbf{2 0 1 3}$ & $\mathbf{2 0 1 4}$ & $\mathbf{2 0 1 5}$ & $\mathbf{2 0 1 6}$ \\
\hline Up to 7 & 14 & 1 & 6 & & 5 & 2 & 5 & 4 & 1 & 10 \\
\hline $8-14$ & 1 & 1 & 1 & 3 & & & 1 & 1 & & 1 \\
\hline $15-18$ & & 1 & & & & & & & & 1 \\
\hline $19-60$ & 56 & 40 & 46 & 32 & 37 & 35 & 39 & 30 & 33 & 38 \\
\hline $61-70$ & 9 & 21 & 16 & 11 & 18 & 20 & 19 & 22 & 19 & 24 \\
\hline over 70 & 27 & 34 & 33 & 32 & 60 & 60 & 40 & 42 & 55 & 55 \\
\hline UNKNOWN & & & & 1 & 2 & 4 & 2 & 4 & 1 & 0 \\
\hline TOTAL & $\mathbf{1 0 7}$ & $\mathbf{9 8}$ & $\mathbf{1 0 2}$ & $\mathbf{7 9}$ & $\mathbf{1 2 2}$ & $\mathbf{1 2 1}$ & $\mathbf{1 0 6}$ & $\mathbf{1 0 3}$ & $\mathbf{1 0 9}$ & $\mathbf{1 2 9}$ \\
\hline
\end{tabular}

\begin{tabular}{|c|c|c|c|c|c|c|c|c|c|c|}
\hline \multicolumn{10}{|c|}{ INJURED } \\
\hline AGE & $\mathbf{1 9 9 5}$ & $\mathbf{2 0 0 0}$ & $\mathbf{2 0 0 5}$ & $\mathbf{2 0 1 0}$ & $\mathbf{2 0 1 1}$ & $\mathbf{2 0 1 2}$ & $\mathbf{2 0 1 3}$ & $\mathbf{2 0 1 4}$ & $\mathbf{2 0 1 5}$ & $\mathbf{2 0 1 6}$ \\
\hline Up to 7 & 14 & 12 & 9 & 14 & 14 & 21 & 3 & 7 & 10 & 5 \\
\hline $8-14$ & 7 & 5 & 11 & 6 & 10 & 7 & 7 & 2 & 9 & 4 \\
\hline $15-18$ & & 4 & 4 & 3 & 7 & 8 & 6 & 3 & 9 & 8 \\
\hline $19-60$ & 86 & 147 & 134 & 160 & 185 & 190 & 168 & 144 & 185 & 189 \\
\hline $61-70$ & 9 & 36 & 15 & 47 & 45 & 48 & 35 & 41 & 44 & 39 \\
\hline over 70 & 11 & 33 & 50 & 54 & 73 & 72 & 76 & 63 & 78 & 53 \\
\hline UNKNOWN & & & & 8 & 3 & 3 & 10 & 3 & 4 & 0 \\
\hline TOTAL & $\mathbf{1 2 7}$ & $\mathbf{2 3 7}$ & $\mathbf{2 2 3}$ & $\mathbf{2 9 2}$ & $\mathbf{3 3 7}$ & $\mathbf{3 4 9}$ & $\mathbf{3 0 5}$ & $\mathbf{2 6 3}$ & $\mathbf{3 3 9}$ & $\mathbf{2 9 8}$ \\
\hline
\end{tabular}

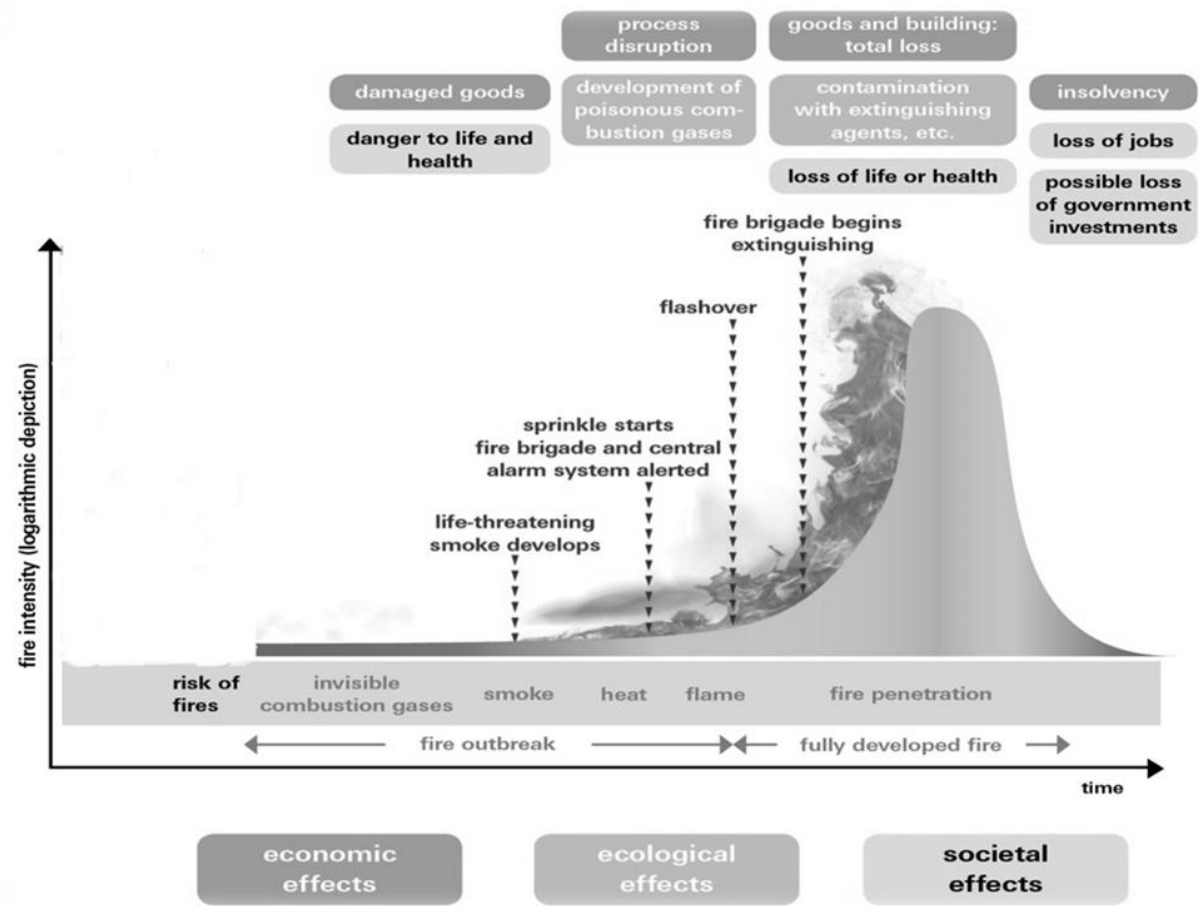

Figure 2. Effects of fires - public health aspects (Source GD"FSCP" - MoI) Trakia Journal of Sciences, Vol. 16, Suppl. 1, 2018 
Health problem link to primary and secondary formed damage factors - flame, heat, soot, poisonous chemicals (carbon monoxide, cyanide, etc.). Toxic chemical traumatism is typical of the injured, besides burns, hypovolemic shock, acute respiratory failure. In the event of a fire, citizens on the territory of the country may request assistance from Bulgaria's single rescue system via 112 . Municipalities and emergency teams of the single emergency system 112 have an action plan for fires and medical insurance for the population.

Response time is important. This reduces risks and losses. Preparing the population for prefire and fire action is a guarantee to improve the output from fires. The training of the medical teams for medical insurance of the population in case of fires is the correct way to reduce the medical casualties.

\section{CONCLUSIONS}

Fires are a global disaster with high risk for the whole territory of Bulgaria. They cause direct and indirect material and non-material damage. The implications for society are complex and wide-ranging. The environmental, socioeconomic and health effects of the population are significant. Traumatism, TChT and respiratory system damage are the main causes of hospitalization. Since 2016, a methodology and mapping of the risk of fires on the territory of the country has been presented, which improves the management and the public health activities. In countries like the US, Russia and Turkey, the fight against forest fires is seen as an element of their national security.

\footnotetext{
Abbreviations

MC - Medical Casualties

$\boldsymbol{T C h}$ - Toxo-chemical Traumatism

$\boldsymbol{R F D}$ - Regional Forestry Directorates

GD"FSCP" - General Directorate "Fire Safety and Civil Protection"

MoI - Ministry of Interior

NSI - National Statistical Institute

MH - Ministry of Health

$\boldsymbol{H L}$ - Health Law

$\boldsymbol{M A F}$ - Ministry of agriculture and food executive forest agency forest sector in the Republic of Bulgaria.
}

\section{REFERENCES}

1. Bulgaria - disaster management structure. Vademecum civil protection, 20.06.2018

2. WHO data of fires, 2018

3. Bulgarian Infrastructure for Spatial Data, BISD, 09.06.2018

4. European Forest Fires Information System (EFFIS), 2018

5. Fire activity for a period of 10 years, Directorate General "Fire Safety and Civil Protection - Ministry of Interior, 2017"

6. MoI data of fires in Bulgaria, 2018

7. Fire Action (ten years period), European Space Agency (ESA), 2017

8. International Fire and Rescue Service Association (CTIF), 2018

9. National Action Plan for the Prevention and Combating of Forest Fires, 2016

10.Forest Fires in Europe, Middle East and North Africa 2016, European Union 2017

11.Forest fire, Project EVANDE, technical report, Center for Educational Initiatives, 2016

12.Methodology for determination of the risk of forest fires on the territory of the country, 2015

13. $\mathrm{MH}$ data of victims of fires in Bulgaria, 2018

14.Strategy for development of voluntary formations for protection against disasters, fires and other emergencies in the Republic of Bulgaria for the period 2012-2020

15.NSI data of fires in Bulgaria, 2018 The National Institute of Meteorology and Hydrology (NIMH) at the Bulgarian Academy of Sciences., 2018 